DOI 10.15290/cnisk.2020.02.09.12

JUSTYNA ZAJKO-CZOCHAŃSKA

https://orcid.org/0000-0001-6414-8280

Uniwersytet w Białymstoku

\title{
Sprawozdanie z Białostockiej Letniej Szkoły Historii Kobiet, Augustów 24 lipca - 2 sierpnia 2020 r. ${ }^{1}$
}

W dniach 24 lipca - 2 sierpnia 2020 r. w Augustowie odbyła się Białostocka Letnia Szkoła Historii Kobiet zorganizowana przez Ośrodek Badań Historii Kobiet Instytutu Studiów Kobiecych przy współpracy Zakładu Historii Kultury, Myśli i Ruchów Społecznych Uniwersytetu w Białymstoku. Tematem przewodnim były badania historii kobiet w Polsce na przykładzie projektów badawczych indywidualnych i zespołowych. W szkole letniej udział wzięli młodzi badacze (doktoranci) wraz z opiekunami naukowymi oraz doktorzy pracujący nad rozprawami habilitacyjnymi. Uczestnicy reprezentowali różne ośrodki naukowe $z$ Polski, m.in. Uniwersytet w Białymstoku, Uniwersytet Marii Curie-Skłodowskiej w Lublinie, Uniwersytet Jana Kochanowskiego w Kielcach oraz Uniwersytet Pedagogiczny w Krakowie. Wśród grona specjalistów znaleźli się historycy, politolodzy, socjologowie, prawnicy oraz medioznawcy prowadzacy badania związane $z$ szeroko pojętą tematyka kobieca.

Obrady merytoryczne zainaugurowała prof. dr hab. Małgorzata Dajnowicz, witając gości oraz przedstawiając idee organizacji szkoły letniej. Jako pierwsza referat pt. Działalność Ligi Kobiet w Małopolsce w latach 1945-1957 zaprezentowała dr Maria Bauchrowicz-Tocka. Pozostając w temacie Ligi Kobiet, jako następna wystapiła mgr Agnieszka

1 Publikacja przygotowana/finansowana w ramach programu Ministra Nauki i Szkolnictwa Wyższego pod nazwa DIALOG w latach 2019-2021. Jest wynikiem udziału w projekcie badawczym pt. „Ośrodek badań historii kobiet”, nr 0016/DLG/2019/10. 
Drozdowska, prezentując część swojej rozprawy doktorskiej, która koncentrowała się na działalności tej organizacji na Białostocczyźnie w latach 1945-1989. Szczególną uwagę w swoim wystapieniu zwróciła na przełomowe momenty w rozwoju organizacji kobiecej na ziemiach północno-wschodnich Polski Ludowej oraz metodologię i źródła, jakie wykorzystuje w swoich badaniach. Ponadto obie prelegentki przybliżyły historię Ligi Kobiet, jak również główne kierunki jej działalności, które koncentrowały się na pomocy potrzebującym kobietom, szczególnie w postaci prowadzenia poradni rodzinnych i prawno-społecznych. Po obu wystapieniach podjęto dyskusję nad prezentowana tematyka, a także przeprowadzono indywidualne konsultacje nad prowadzonymi badaniami. Pierwszy dzień spotkania zakończyło przybliżenie przez prof. dr hab. Małgorzatę Dajnowicz celów działalności Ośrodka Badań Historii Kobiet. Pomysłodawczyni zaprezentowała poczynania Stowarzyszenia, funkcjonowanie „Czasopisma Naukowego Instytutu Studiów Kobiecych”, a także zaznajomiła $z$ celami projektu „DIALOG” finansowanego w ramach programu Ministra Nauki i Szkolnictwa Wyższego w latach 2019-2021.

W kolejnym dniu podjęto rozważania dotyczące czasopisma kobiecego „Zwierciadło”. Prof. dr hab. Małgorzata Dajnowicz przedstawiła obraz kobiety sukcesu na łamach „Zwierciadła”, pisma Ligii Kobiet Polskich w latach 1982-1989. Dr Anna Szwed-Walczak zaprezentowała zaś Obraz feminizmu na łamach polskiej prasy dla kobiet w latach 1989-1992. Autorka wystapienia poddała analizie najpopularniejsze czasopisma dedykowane kobietom w omawianym okresie, tj. „Przyjaciółkę”, „Kobietę i Życie”, „Zwierciadło”, „Filipinkę” oraz „Urodę”. Jako ostatnia tego dnia głos zabrała dr hab. prof. UP Magdalena Mikołajczyk, prezentując referat pt. Kontestatorki. Zaangażowanie opozycyjne (semiopozycyjne, quasiopozycyjne) kobiet w PRL po 1955 roku. Po każdym wystapieniu zadawano pytania prelegentkom oraz udzielano wskazówek. W ramach realizacji zaplanowanego, bogatego programu kulturalnego organizatorzy zabrali uczestników na rejs katamaranem po meandrach Pojezierza Augustowskiego. Żegluga obejmowała rzekę Nettę, jezioro Necko, rzekę Klonownicę (najkrótszą rzekę żeglowna w Europie), jezioro Białe oraz jezioro Rospuda. Dzięki wycieczce uczestnicy mieli okazję poznać historię wyprawy armii napoleońskiej do Rosji wiodacej przez okolice obecnego Kanału Augustowskiego, jak również podziwiać unikatowe, chronione gatunki roślin i zwierząt.

W następnym dniu szkoły letniej wystapiła mgr Justyna Zajko-Czochańska, referując część badań podjętych w celu przygotowania pracy 
doktorskiej. Prezentacja dotyczyła roli tygodnika „Przyjaciółka” w życiu kobiet społeczności wiejskiej ze szczególnym uwzględnieniem edukacyjnej roli czasopisma w latach 1956-1975. Doktorantka przybliżyła historię najbardziej poczytnego czasopisma kobiecego okresu PRL, jego cechy formalno-wydawnicze, stosowana metodologię wykorzystywaną do badań nad tygodnikiem oraz formy upowszechniania wiedzy stosowane przez redakcję periodyku. Dr Diana Dajnowicz-Piesiecka skoncentrowała się natomiast na zaprezentowaniu ustawodawstwa dotyczacego rodziny i kobiet w Polsce Ludowej. Prelegentka przeanalizowała historię i rozwój aktów prawnych na rzecz ochrony praw kobiet. Po referatach przeprowadzono dyskusję, wniesiono uwagi oraz spostrzeżenia do podniesionych kwestii. W godzinach popołudniowych po zakończonych obradach i warsztatach została zorganizowana kolejna atrakcja kulturalna. Nadleśnictwo Augustów zabrało uczestników na wycieczkę do Puszczy Augustowskiej, gdzie mieli okazję podziwiać jeden $z$ największych w Polsce kompleksów leśnych. Poza dzika przyroda podczas wyprawy odwiedzono także miejsca historyczne ważne dla tego regionu Polski. Jedna $z$ atrakcji była wierna rekonstrukcja partyzanckiej ziemianki, gdzie pierwotnie funkcjonowała. Ponadto odwiedzono sanktuarium maryjne w Studzienicznej zwiazane z objawieniami Matki Boskiej, które miały miejsce w XVIII w., a także z wizyta w 1999 r. Papieża Jana Pawła II podczas pielgrzymki do Polski.

Kolejny dzień spotkania poświęcony był prasie kobiecej okresu PRL. Dr Łukasz Jędrzejski zaprezentował referat pt. Dyskurs polityczny w Polskiej Rzeczpospolitej Ludowej na łamach tygodnika „Zwierciadło” $w$ latach 1970-1980. Dr Urszula Sokołowska swoje wystapienie oparła zaś na pierwszym czasopiśmie skierowanym do nastolatek - „Filipince”. Prelegentka przybliżyła specyfikę pisma, odbiorców oraz podejmowana tematykę $z$ głównym naciskiem na edukacyjna rolę periodyku w latach 1957-1989. Po każdym wystapieniu uczestnicy spotkania żywo dyskutowali nad zaprezentowaną tematyką. Po zakończonej w tym dniu części merytorycznej w ramach dodatkowych atrakcji udano się do Muzeum Ziemi Augustowskiej, gdzie poznano m.in. historię Kanału Augustowskiego - zabytku województwa podlaskiego będącego Pomnikiem Historii. Ponadto w muzeum zapoznano się $z$ dokumentem potwierdzajacym prawa przedmieszczanom Augustowa $z$ podpisem króla Stanisława Augusta Poniatowskiego z 1792 r. oraz rękopisami Ignacego Prądzyńskiego $z$ lat 1823-1824. Następnie uczestnicy udali się na śluzę Paniewo znajdująca się na Kanale oraz mieli okazję uczestniczyć w śluzowaniu. 
Ostatniego dnia szkoły letniej jako pierwsza wystapiła prof. dr hab. Jolanta Chwastyk-Kowalczyk z referatem pt. „Prasowite zdziwienia” Katarzyny Bzowskiej-Budd-przedstawicielki polskiego dziennikarstwa fali emigracji „solidarnościowej”. Prelegentka zaprezentowała postać polskiej dziennikarki mieszkającej i pracującej w Londynie. Emigrantka lat 80. trwale wpisała się w pejzaż publicystyczny naszej diaspory, była redaktorką naczelną londyńskiego „Dziennika Polskiego i Dziennika Żołnierza”, tym samym stała się inspiracją do badań. Następnie wyniki swoich dociekań naukowych przedstawiały doktorantki mgr Agnieszka Śliwa oraz mgr Agnieszka Warzyńska. Pierwsza z pań zaprezentowała wybrane przykłady prasy regionu kieleckiego w Polsce Ludowej, scharakteryzowała wybrane instytucje kultury, ze szczególnym uwzględnieniem instytucji zakładowych, a także przedstawiła czasopismo „Walczymy o Stal” oraz prezentowane w nim życie społeczne i kulturalne. Mgr Agnieszka Warzyńska skoncentrowała się zaś na magazynie „Playboy”, wygłaszając referat pt. Felietonistki „Playboya”. Kobiety publikujace na łamach polskiej edycji magazynu „Playboy” w latach 1992-2019. Analiza prasoznawcza gatunku. Doktorantka w swoim wystapieniu zaakcentowała, iż felietony autorstwa znanych dziennikarek w polskiej edycji magazynu charakteryzowały się poczuciem humoru, smakiem, swobodą oraz sarkazmem.

Uzupełnieniem części merytorycznej spotkania było zaprezentowanie wydawnictwa Instytutu Studiów Kobiecych (Wydawnictwa HUMANICA) ze szczególnym uwzględnieniem „Czasopisma Naukowego Instytutu Studiów Kobiecych”. Po wszystkich wygłoszonych referatach, podjętych nad nimi dyskusjach, warsztatach oraz indywidualnych i grupowych konsultacjach organizatorka wydarzenia prof. dr hab. Małgorzata Dajnowicz podsumowała kilkudniowe obrady. Podziękowała wszystkim uczestnikom za udział oraz owocne spotkanie, zamykajac tym samym pierwszą Białostocką Letnią Szkołę Historii Kobiet. 